\title{
Organizational Learning and Hotel Performance: The Role of Capabilities' Hierarchy
}

\begin{abstract}
Building on the capabilities' hierarchy concept, a model of the effect of organizational learning on hotel performance is proposed and tested in this study. Data was collected from 240 managers in the hotel industry of United Kingdom and Pakistan via survey. The results revealed strong direct inter-relation between different level of capabilities and an indirect relation between organizational learning and performance through these capabilities. This paper makes theoretical contributions to both management and hospitality and tourism research by generating an integrative and unifying framework for an organizational learning performance relationship, clarifying capabilities inter-relationships and empirically revealing the exact way these capabilities enhance performance. Also, it has practical implications for hotel managers' understanding on the development and use of capabilities as a hierarchy in enhancing their hotel performance.
\end{abstract}

Keywords: Organizational Learning; Dynamic and Substantive Capabilities; Capabilities' hierarchy; Organizational Performance; Hotel industry.

\section{Introduction}

The importance of organizational learning has a long lineage in management as well as hospitality and tourism research. There have been several studies investigating the effects of organizational learning on organizational performance in both these disciplines (e.g., Sinkula et al., 1997; Schauffer and Walluer, 2003; Tajeddini et al., 2017; García-Villaverde et al., 2017; Shamim et al., 2017; Oh, 2019). The earlier work on organizational learning was mainly conceptual and contradictions emerged due to the lack of related empirical work (Lord and Ranft, 2000; Prieto and Revilla, 2006). For example, Sinkula et al. (1997), Bontis, et al. (2002), Schauffer and Walluer (2003), Bustinza, et al. (2010) proposed that organizational learning generates novelty in products, procedures, and systems leading directly to better performance. Alternatively, learning is seen as a means of developing organizational capabilities which in turn lead to better performance and competitive advantage (e.g., Easterby-Smith and Prieto, 2007; Capeda and Vera, 2005; Fraj et al., 2015; Liu, 2017, 2018). Therefore, the nature of the relationship between organizational learning and performance remained to be defined clearly (Zgrzywa-Ziemak, 2015). Also, the manner of measuring performance in relation to organizational learning has not reached a consensus (Goh et al., 2012). The earlier hotel performance measurement systems were weak in some areas and did not cope with the fundamental orientation and industry context (Geller, 1985). Therefore, authors (e.g., Kaplan and Norton 1992; Brander and McDonnell, 1995; Bontis et al., 2002; Bozic and Cvelbar, 2016) suggested using both economic and non-economic performance measures as a more comprehensive approach while assessing hotel efficiency. Recently, Sainaghi et al. (2019) also called for an alignment between rigor and relevancy while measuring performance in hotel sector. 
Also, the gap of empirical investigation of inter-relation between organizational learning and other levels of capabilities is evident in both management and hospitality and tourism research. In management literature, organizational learning, dynamic, and substantive capabilities have been differentiated (Easterby-Smith and Prieto, 2007) and ranked in a hierarchy of capabilities as second, first and zero order capabilities respectively (Collis, 1994 and Winter, 2003). However, empirical testing of this inter-relation is very rare (Chien and Tsai, 2012), has not been sufficiently valued (Helfet et al., 2007) and there is still a lack of detailed knowledge of how these capabilities are intertwined (Peteraf et al., 2013). Similarly, in hospitality and tourism research, Brockman and Morgan (2003), Argote and Miron-Spektor (2011), Bozic and Cvelbar (2016) revealed that organizational learning sometimes functions as a core rigidity hindering the development of hotels' capabilities. While others (e.g., Nieves and Haller, 2014 and Liu, 2017, 2018) believed that the view of a knowledge based organizational learning approach enhance hotels' capabilities. This led Nieves and Haller (2014) to state that the nature of the link between these capabilities remained ambiguous.

Moreover, many researchers have defined dynamic and substantive capabilities, distinguished them from each other as first and zero level capabilities and investigated their effect on organizational performance. However, they remained sceptical and differed in their views about their true nature and the exact way they affect performance (Winter, 2003; Peteraf et al., 2013). The literature on dynamic capabilities has been criticized for its vague assertions and interpretations (Protogerou et al., 2008) and confusion around the construct (Di Stefano et al., 2014). Dynamic capabilities have been termed tautological (Priem and Butler, 2001), ineffective in achieving competitive advantage (Eisenhardt and Martin, 2000) and the way they affect performance remained unclear (Protogerou et al., 2005; Helfat et al., 2007; Peteraf et al., 2013; Di Stefano et al., 2014; Ringov, 2017). Scholars examining the dynamic capabilities-performance relationship are divided into two different groups. Researchers such as Henderson and Cockburn (1994) and Deeds et al. (1999) among others believed in the direct effect of dynamic capabilities on firm performance. While others (e.g., Eisenhardt and Martin, 2000; Winter, 2003; Zahra, et al., 2006; Easterby-Smith and Prieto, 2007; Protogerou et al., 2008; Peteraf, et al., 2013) believed in an indirect effect through substantive capabilities.. Taking these into consideration, Prieto et al. (2009), Hung et al. (2010), Chien and Tsai, (2012) and Namada, (2017) called for research to clarify the nature, antecedents, and consequences of these capabilities in order to generate a unifying framework.

In response to the above mentioned research gaps and calls in management as well as hospitality and tourism literature, this study aims to proposes a model of the effect of organizational learning on performance and tests it empirically through the mediating role of an organization dynamic and substantive capabilities. As such this study has two goals. The first goal is to reveal the nature of relationship between organizational learning and the economic and noneconomic performance indicators of an organization. In doing so it will attempt to clarify whether organizational learning leads directly to better performance or works through the development of organizational capabilities which in turn lead to better performance. Moreover, it will also attempt to establish a useful method of measuring hotel performance in relation to organizational learning. The second goal of this study is to empirically test the inter-relation among different levels of capabilities and their effect on performance. This will not only clarify uncertainty in the literature about their inter relationships but will also provide detailed information about the way they 
enhance performance. In other words, this study will produce an integrative and unifying framework showing the antecedents and consequences of these different levels of capabilities.

We have chosen hospitality industry as a context for this study because it has been observed that being new disciplines, tourism and hospitality are inclined towards models and concepts derived from the management literature (Assaf and Cvelbar, 2011). And the gap of revealing the exact inter-relation between different capabilities and their effect on performance is evident in both disciplines. However, despite these common concerns, there have been very little attempts to integrate understandings from both these sides into a unifying framework in solving these issues. It has also been observed that there are many studies on the effect of organizational learning on hotel performance in developed countries. However, the study of learning orientation and its effect on hotel performance in a developing country context has been scant (Sin et al., 2005) especially in Pakistan (Amana et al. 2010). The context of this study, specifically, the hotel sector in United Kingdom and Pakistan will also provide insights into the effect of organizational learning on performance in the developed as well as developing country context. In this regard, Kusluvan and Karamustafa (2001) asserted that hotels which are similar in their nature have similar effects in terms of the impact of organizational learning on performance - irrespective of their country. The empirical investigation in this study will be an attempt to confirm Kusluvan and Karamustafa (2001) assertion. Also it will check the generalizability and applicability of our proposed model across the disciplines of management and hospitality.

In order to achieve the goals of this study, we will first review management as well as hospitality and tourism literature in order to integrate understandings from both these sides into a unifying organizational learning-performance framework and develop formal hypothesis. We will then propose data collection and analysis methods to test the proposed hypothesis. At the end, we will draw conclusions of our study along with its academic and practical contributions, point out limitations of this study and will give directions for further research.

\section{Theory and Hypotheses Development 2.1. Organizational Learning and Dynamic Capabilities}

Organizational learning received great attention among academics and practitioners during the 1970 s to 1990 s because of the increasing pressure and pace of change on organizations. This earlier literature on organizational learning was developed along two distinct lines. The first emphasized the concept that employees constantly learn from casual practices and everyday interactions with one another in their organization. The second school of thought conceptualized organizational learning as a process concerned with gathering information and diffusing the knowledge acquired. Following this period, the organizational learning was conceived to be closely related to knowledge management (e.g., Nonaka, 1994; Andrews and Delahaye, 2000). This literature proposed that the organizational learning process was one that was social, collective, situated in practice and comprised of knowledge acquisition, distribution, interpretation, and codification (e.g., Huber, 1991; Sinkula, 1994; Santos-Vijande et al., 2012). Later on, Bartsch et al, (2013), Nieves and Haller (2014), Liu (2018) maintained that one of the indications of organizational learning in an organization is the use of newly gained knowledge. This recognition 
of the process of managing knowledge potentially enhances our understanding of how organizational learning occurs. Also, this conceptualization of organizational learning is one that has been used in research in the hospitality and tourism industry (e.g., Lemmetyinen and Go, 2009; Thomas and Wood, 2015).

Similarly, the concept of dynamic capabilities has also been researched since the 1990s in the strategic management literature. Different authors have tried to define dynamic capabilities in order to reveal their true nature. For example, Teece et al. (1997) referred to these as integration and reconfiguration abilities to cope with turbulent environments. Eisenhardt and Martin (2000) conceptualised these as an organization's strategic routines to obtain new configurations of resources in a changing environment. According to Zahra and George (2002) dynamic capabilities brought changes through reconfiguring resources. Dynamic capabilities improved an organization's performance through learned and stable patterns of collective activity (Zollo and Winter, 2002). The dynamic capabilities view as a developed concept from the resource based and knowledge-based views of the firm (Lopez, 2005). Helfat et al. (2007) termed dynamic capabilities as the organization's ability to create, extend, and modify its resources persistently. For Sirmon et al. (2007) dynamic capabilities are choices made in the structuring, bundling, and leveraging its resources. Likewise, Teece (2007) suggested sensing, shaping and seizing opportunities and threats, and enhancing, combining, protecting, and reconfiguring the business enterprise's intangible and tangible assets as micro-foundations of dynamic capabilities. Helfat and Peteraf (2009) noted that dynamic capabilities address the questions of how to sustain advantage in a turbulent environment. Analysing all these definitions of dynamic capabilities revealed that a convergence of views on dynamic capabilities emerged which agreed on conceptualizing dynamic capabilities as adaptive capability, absorptive capability, and innovative capability (Wang and Ahmed, 2007) with the underlying processes of integration, reconfiguration, renewal, and recreation (Ali et al., 2012). For this study we agree with Wang and Ahmed (2007) and Ali et al. (2012) conceptualization of dynamic capabilities that pooled lines from not only the content but also the process sides of the strategy field in order to better define dynamic capabilities.

However, despite this vast literature about organizational learning and dynamic capabilities, there was very little literature on their inter-relationship (Peteraf et al., 2013; Bozic and Cvelbar, 2016) and where dynamic capabilities come from. Therefore the nature of the link between organizational learning and capabilities remains ambiguous (Nieves and Haller, 2014). This was because previously there was a conflict in the literature regarding the role of organizational learning and knowledge in the development of organization dynamic capabilities. Authors such as Argote and Miron-Spektor, (2011) and Brockman and Morgan, (2003) revealed that organizational learning sometimes functions as a core rigidity hindering the development of hotels' capabilities. Therefore, Mahoney (1995) and Zollo and Winter (2002) suggested that examination of the processes by which firms learn is critical to understanding the development of dynamic capabilities. Later work on organizational learning has seen it as the process of creating and using of knowledge throughout an organization for the purpose of developing its dynamic capabilities (Winter, 2003; Chien and Tsai, 2012). Zollo and Winter (2002) viewed learning and knowledge management as a facilitator of dynamic capabilities' development. The hierarchy view of Winter (2003) and Easterby-Smith and Prieto (2007) also proposed learning as a second order capability facilitating the creation and modification of dynamic capabilities. Moreover, in the field of hospitality and tourism, the work of Nieves and Haller, (2014) and Leonidou et al., (2015) 
revealed that the view of knowledge based on an organizational learning approach can enhance hotels' dynamic capabilities. Also, Fraj et al. (2015) revealed that organizational learning in a hotel helps in the development of the innovation capabilities. Recently, it is claimed that organizational learning is a principle means of strategic renewal of the organization (Namada, 2017). Also, Liu (2017) found that the development of the capability of cognitive social capital is enhanced by exploitative learning. Moreover, Liu (2018) posited that organizational learning linked the capabilities of social capital and knowledge transfer. Therefore, we propose that

Hypothesis 1: Organizational learning processes positively and directly influence the development of organization dynamic capabilities.

\subsection{Dynamic Capabilities and Substantive Capabilities}

In the literature dynamic capabilities have been clearly distinguished from substantive capabilities. The management literature has recognized marketing and technological capabilities as important substantive capabilities (e.g., Day, 1994; Danneels, 2002; Wilden and Gudergan, 2015). Marketing capabilities are considered as the abilities of a firms to know and serve their customers' needs and evaluate competition (Fowler et al., 2000) and have been categorized as outside-in, inside-out and spanning capabilities by authors like Day (1994), Pavlou and El Sawy (2004), Vorhies and Harker (2000), Protogerou et al. (2005), Song et al. (2005), Vorhies and Morgan, (2005). According to these authors, a firm's outsidein capabilities enable it to sense changes in the market, respond and build relationship with the market. A firm's inside-out capabilities are its internal human and technological resources and capabilities, and spanning capabilities combine inside-out and outside-in to facilitate strategy implementation. Similarly, technological capabilities are termed as the abilities that enable firms to be involved in shared problem solving, prototype development and technological knowledge absorption (Leonard-Barton, 1995) and constituted a firm's know how about product and service design, engineering and manufacturing and quality control (Danneels, 2002).

Besides distinguishing dynamic capabilities from substantive capabilities and defining what substantive capabilities are, researchers have also tried to link dynamic capabilities directly to the development of substantive capabilities. For example, Collis (1994) differentiated dynamic as second order capabilities and substantive as first order capabilities. For him substantive capabilities were the abilities of organizations to perform the basic functional activities like marketing, assembling and distribution while he considered dynamic capabilities as abilities of organizations to deal with the dynamic improvements to these substantive capabilities. Also for Winter (2003:992) an organization with substantive capabilities only would be "living by producing and selling the same product, on the same scale and to the same customer population over time". While an organizations with dynamic capabilities would constantly renew their substantive capabilities for achieving long-term competitive advantages (Ali et al., 2012). For Zahra et al. (2006) an organization with substantive capabilities only would be able to develop a routine for new product development 
but an organization with dynamic capabilities would be able to change and renew such routines and abilities continuously. Vargo and Lusch, $(2004,2008)$ in their Service Dominant (S-D) logic took a similar view when they recognized and differentiated two types of resources: operant and operand. For these authors operant resources were keys to innovate an organization current products and operations i.e. the operand resources. Teece (2007) also considered dynamic capabilities to change organizations' substantive capabilities. Danneels (2008) considered dynamic capabilities to align substantive capabilities. For Helfat \& Winter (2011) dynamic capabilities alter the way an organization obtains its survival and Protogerou et al. (2011) considered dynamic capabilities as a mean to renew its substantive capabilities. Thus, dynamic capabilities are considered to be an organization's capacities in creating, extending, and modifying its substantive capabilities. Based on the above discussion, we propose that:

Hypothesis 2: An organization's dynamic capabilities positively and directly enhance its substantive capabilities.

\subsection{Substantive Capabilities and Firm/Hotel Performance}

In linking dynamic and substantive capabilities to an organization performance, researchers have now revealed that dynamic capabilities do not enhance performance directly. Rather, they work through modifying the substantive capabilities which in turn not only lead to sustainable competitive advantage but also to superior performance. (e.g., Clark and Fujimoto, 1991; Pisano, 1994; Song et al, 2005: Leonidou, et al., 2015; Wilden and Gudergan, 2015). Easterby-Smith and Prieto (2007:245) found that substantive capabilities are "...geared towards the operational functioning of the firm and can affect performance measures and lead to aboveaverage returns." According to Siggelkow and Levinthal (2005) substantive capabilities are essential for running routine processes and activities and are related to a firm's performance. Further, substantive capabilities represent the complex chains of individual and organizational routines which when targeted towards a specific functional purpose, lead to specific organizational capabilities such as distribution capabilities (Baiter, 2004) and relationship building in hospitality and tourism sector (Lemmetyinen and Go, 2009).

In particular, marketing capabilities' role in explaining performance has been the topic of research throughout the history of the marketing discipline (Morgan, 2012). Vorhies et al., (1999) considered that organizations with market-driven capabilities outperform their competitors in terms of organizational performance. Hooley et al., (2005) and Ramaswami et al., (2009) found that the marketing capabilities affect financial performance of a firm. Further, Wilden and Gudergan (2015) revealed that marketing capabilities help a company create and maintain relationships with customers leading to enhanced performance.

Similarly, technological capabilities have also been connected with superior performance in the literature. For example, according to Protogerou et al. (2005) the result of marketing and technological capabilities is the development of technically viable products addressing specific customer needs. For Song et al., (2005) the technological capabilities affect firm performance irrespective of the degree of technological turbulence while the effect of marketing capabilities is bound with the degree of technological turbulence. Also, Chen et al., (2009) revealed that 
technological capabilities of an organization have an effect on its new venture performance. Based on these evidences, we propose that:

Hypothesis 3: An organization's substantive (i.e. marketing and technological) capabilities positively and directly enhance its performance.

\subsection{Mediating Relationships}

\subsubsection{Mediating Role of Dynamic Capabilities}

Although the inter-relation between organizational learning, dynamic and substantive capabilities has been recognized widely in both management and hospitality literature a detailed knowledge of the exact relationship among these capabilities remains lacking orambiguous (Peteraf et al., 2013; Nieves and Haller, 2014; Bozic and Cvelbar, 2016). To clarify this ambiguity, a capabilities hierarchy has been differentiated as zero, first and second order capabilities which not only inherently linked substantive, dynamic and learning capabilities but also showed the place of dynamic capabilities up and down the capabilities hierarchy (Collis, 1994; Winter, 2003). In this regard, Capeda and Vera (2005, p. 427) argued that a consensus among the researchers has emerged about the need for a hierarchy of capabilities in which dynamic capabilities took as an input an initial configuration of a firm's knowledge resources and operational routines, transformed them and produced an output in the form of new configuration of resources and operational routines. Going a step further, Easterby-Smith and Prieto (2007, p.237) clearly stated that "...operational capabilities or routines are geared towards the operational functioning of the organization; dynamic capabilities are dedicated to the modification of operational routines; and finally, learning capabilities facilitate the creation and modification of dynamic capabilities."

Linking these evidences of mediating role of dynamic capabilities with our first and second hypothesis $(\mathrm{H} 1, \mathrm{H} 2)$, we can predict that substantive capabilities are shaped by dynamic capabilities which in turn are created and modified by the learning process. This is in accordance with the Archer's (1995) model of social action, in which pre-existing conditions influence the way in which agents and structural features interact to either reproduce or transform social action. That is, it is the social integration mechanisms enable knowledge exchanges that are vital to organizational learning and its translation into useful capabilities. Therefore we propose:

Hypothesis 4: An organization's dynamic capabilities mediate the organizational learningsubstantive capabilities relationship.

\subsubsection{Mediating Role of Substantive Capabilities}

In the earlier literature dynamic capabilities have been termed tautological (Priem and Butler, 2001) and the way these affect performance remained unclear (Winter, 2003; Peteraf et al., 2013; Protogerou et al., 2005). Latterly, researchers revealed that dynamic capabilities work 
through modifying an organization's substantive capabilities which in turn enhanced performance (Eisenhardt and Martin, 2000; Winter, 2003; Zahra et al., 2006; Helfat and Peteraf, 2003; Peteraf et al., 2013; Leonidou et al., 2015). Similarly, Helfat and Peteraf (2003), Capeda and Vera (2005), Zahra et al., (2006), Easterby-Smith and Prieto (2007) also revealed that the dynamic capabilities indirectly enhance performance through an impact on substantive capabilities. Zott (2003) confirmed the mediated relation between dynamic capabilities and firm performance through simulation analysis. Protogerou et al. (2011) also empirically revealed the mediating role of marketing and technological capabilities as mediators in dynamic capabilities performance relationship. Recently, Mu (2017) and Takahashi et al. (2017) revealed marketing capabilities as mediator in dynamic capabilities performance relationship. Similarly, in the hospitality and tourism sector, Fraj et al. (2015) revealed that capabilities in a hotel affect organizational competitiveness only indirectly.

In linking these evidences with our second and third hypothesis ( $\mathrm{H} 2$ and $\mathrm{H} 3$ ), we predict an indirect effect of dynamic capabilities on performance through the mediating role of substantive capabilities in accordance with Archer's (1995) model of social action whichimplies the need for the creation of durable conditions for action (such as established social practices) to facilitate the translation of dynamic capabilities into enhanced organizational performance.. Therefore we propose:

Hypothesis 5: An organization's substantive capabilities mediate the dynamic capabilities-performance relationship.

Figure 1 displays the proposed conceptual framework for this study. This framework for the effect of organizational learning on a performance portrayed the two types of relationships. First, the direct relationships as shown by the arrow that is the direct relationship between organizational learning processes and dynamic capabilities (H1), the direct relationship between dynamic and substantive capabilities (H2) and the direct relationship of substantive capabilities and performance (H3). Second, the indirect (mediated) relationships as depicted by the dotted arrow $1-\ldots+\hat{\jmath}$ that is, the mediating role of dynamic capabilities in organizational learning -substantive capabilities relationship (H4) and the mediating role of substantive 
capabilities in dynamic capabilities-firm performance relationship

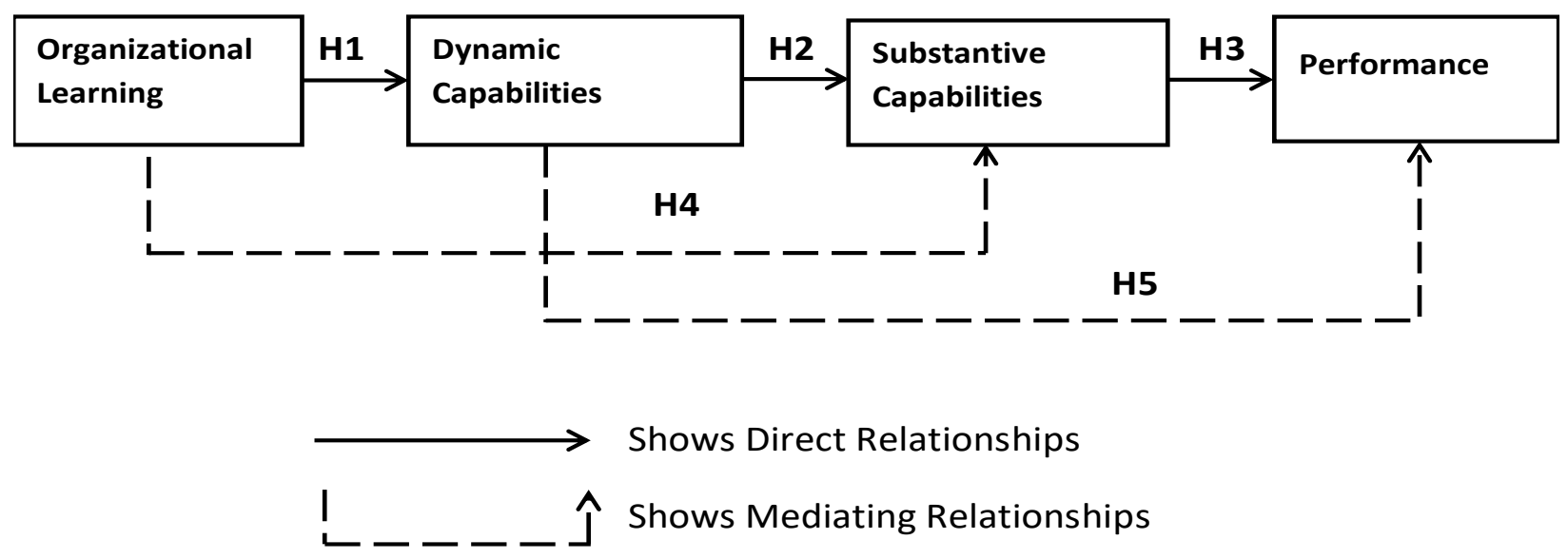

Figure 1: Conceptual Framework

\section{Methods}

\subsection{Sample and Data Collection}

To test the proposed hypothesis, data was collected from key informants i.e. chief executive officers, marketing and IT managers as well as other managers in the United Kingdom and Pakistan hotels via survey. We used non-probability purposive and convenience sampling methods in the selection of mangers and hotels to participate in the survey because of the inability to adequately estimate the target population, especially in Pakistan. Also surveyed only those managers who had at least five years of experience as they were expected to be knowledgeable about the processes underlying dynamic capabilities (Chen et al., 1993). Similarly, only those larger hotels were selected for the survey as these were likely to have more established procedures when compared to smaller hotels which might have less formalized roles and their different departments might have different routines related to dynamic capabilities, making it unsuitable in smaller companies to then generalize them for the company as a whole (Wilden et al., 2013). However, to avoid unrepresentativeness bias associated with this sampling method, the researcher randomly reached extra sample units (hotel mangers) through e mail, postal and high street access. The sample used in this study is summarised in Table 1. 
Table 1

Summary of Survey Respondents

\begin{tabular}{lll}
\hline No of Managers Surveyed & 1150 & Percent \\
\hline Responses & 300 & \\
Valid Responses & 240 & $(20) \%$ \\
Response rate (\%) & & \\
Ranking \&employees & & $(14.5 \%)$ \\
\hline S Star, >300 employees & 35 & $(48.7 \%)$ \\
4 Star, >300 employees & 117 & $(36.6 \%)$ \\
3 Star/others, =<300 employees & 88 & \\
Total & 240 & \\
Method of Response & & $(76.6 \%)$ \\
\hline Survey URL/ E mail & 184 & $(23.3 \%)$ \\
Post/ In person & 56 & \\
Time of Response & & $(50.4 \%)$ \\
\hline Early & 121 & $(30 \%)$ \\
First Reminder & 72 & $(19.5 \%)$ \\
Second Reminder & 47 & $(47 \%)$ \\
Job Role & & $(30 \%)$ \\
\hline General Manager & 113 & $(13.3 \%)$ \\
Marketing Manager & 72 & $(6.25 \%)$ \\
IT Manager (CIO) & 32 & \\
Other & 15 & \\
\hline
\end{tabular}

The questionnaire was sent to 1150 hotel managers, 750 in the United Kingdom and 400 in Pakistan. The link to the survey at "Surveymonkey.com" was sent to the hotel managers in the United Kingdom through the "Institute of Hospitality". In Pakistan managers at hotels listed with, Pakistan Tourism Development Corporation, Hashoo Group, Tourism Promotion Services (TPS Serena), Ministry of Tourism Pakistan and other registered corporations were approached. A total of 300, 180 from UK and 120 from Pakistan, surveys were returned by hotel managers. However, 240 full completed responses, 135 United Kingdom and 105 Pakistan, were used in the final data analysis which are more than Faul et al. (2007) suggestions of an ideal sample size of 200 for a medium effect size (1- $\beta-0.8 \alpha=0.05)$. We present the United Kingdom and Pakistan data as one set in this paper. However, to ascertain country bias, we examined the data sets separately but did not find any significant differences between them.

\subsection{Measures}

The constructs used in this study are organizational learning, dynamic capabilities substantive capabilities and performance. In order to measure organizational learning, we used the most widely tested and validated organizational learning scale (see Lopez, et al., 2004) which measures learning as a process of "knowledge acquisition, distribution, interpretation and organizational memory". 
To measure dynamic capabilities, we utilized the scale developed by Ali et al. (2012) who considered these as a broader latent construct consisting of three lower-order interrelated factors of integration, reconfiguration and renewal (recreation) capabilities. Similarly, in order to measure substantive capabilities, we utilized the scale developed by Ali et al. (2012) which contained items measuring both marketing and technological-related capabilities.

In measuring performance, we drew upon the work and suggestions of Brander and McDonnell (1995), Kaplan and Norton (1992), Bozic and Cvelbar (2016) and Sainaghi et al. (2019) and conceptualized the hotel performance as a construct representing both economic and non-economic performance measures. Economic performance was measured through a four-item scale: self-reported occupancy rate, return on investment (ROI), gross operating profit, and cash flow. Customer satisfaction and innovation were used to measure non-economic performance. Further, we utilized the method proposed by Fraj et al. (2015) and Bozic and Cvelbar. (2016) who recommend asking hotel managers to evaluate their performance compared with their main competitors on a 5 point Likert scale and use primary quantitative data to evaluate performance in hotels.

\section{Data Analysis and Results \\ 4.1. Analysis Technique}

Partial least square path modelling techniques, which that has been extensively used in strategic management and organizational learning disciplines (Peng and Lai, 2012) were used in this study. Dale et al. (2012) argued that detecting the actual paths, the PLS is as effective as other SEM techniques. However, they concluded that like the other techniques it also suffers from increased standard deviations, decreased statistical power, and reduced accuracy problems.

\subsubsection{Direct relationships}

Before checking the hypothesized direct relationships among the constructs using SEMPLS modelling in Smart-PLS 2.0 M3, we first assessed the measurement or outer models for validity and uni-dimensionality as according to Chin's, (1998a) two-step approach for evaluating the partial model structures. The sample characteristics were investigated according to potential for bias amongst responses to the survey. None of the means for any of the variables differ significantly ( $p>.05$ ) with respect to the response time, survey method and job of the respondent. Also the descriptive statistics (Table A.1, Appendix A) and test of measures were done using both SPSS and Smart-PLS. We used non-parametric bootstrapping (Chin, 1998a and Tenenhaus et al., 2005) for estimating the parameters in the model and obtained first and second order loadings estimates, standard error and t statistics for inferential purposes. The Item/Indicator loadings and $\mathrm{T}$ values were all significant at $\mathrm{P}<0.001$ level (Table 2 below and Table B.1, Appendix B) The model fit statistics were all above the conventional cut-offs for reliability, greater than 0.70 for composite reliability (CR) and 0.50 for Average Variance Extracted (AVE) (Table 3). All these results revealed robustness of our data.

\section{Table 2}


Loadings of the first order construct on their respective second order constructs in null model (Sig at $\mathbf{P}<0.001)$

\begin{tabular}{|c|c|c|c|c|c|c|}
\hline & DC & IIT & MKR & NECO & ECO & OL \\
\hline CR & 0.981 & 0.954 & 0.927 & 0.906 & & 0.965 \\
\hline AVE & 0.813 & 0.700 & 0.599 & 0.706 & & 0.697 \\
\hline DC1 & 0.928 & & & & & \\
\hline DC2 & 0.970 & & & & & \\
\hline DC3 & 0.972 & & & & & \\
\hline IIT1 & & 0.794 & & & & \\
\hline IIT2 & & 0.948 & & & & \\
\hline IIT3 & & 0.912 & & & & \\
\hline MKR1 & & & 0.759 & & & \\
\hline MKR2 & & & 0.810 & & & \\
\hline MKR3 & & & 0.953 & & & \\
\hline NECO1 & & & & 0.859 & & \\
\hline $\mathrm{NECO} 2$ & & & & 0.896 & & \\
\hline ECO1 & & & & & 0.843 & \\
\hline $\mathrm{ECO} 2$ & & & & & 0.837 & \\
\hline ECO3 & & & & & 0.859 & \\
\hline ECO4 & & & & & 0.829 & \\
\hline OL1 & & & & & & 0.718 \\
\hline OL2 & & & & & & 0.940 \\
\hline OL3 & & & & & & 0.929 \\
\hline OL4 & & & & & & 0.940 \\
\hline
\end{tabular}

"Dc= Dynamic Capabilities, IIT= information Technology Related Capabilities, SC= Substantive capabilities, OL= Organizational Learning process, $\mathrm{MKR}=$ Marketing Capabilities, $\mathrm{PERF}=$ Performance, $\mathrm{ECO}=$ Economic Performance, NECO $=$ Non-Economic Performance"

\section{Table 3}

Loadings and CR/AVE of the second order construct on its respective third order construct in null model (Sig at $\mathbf{P}<\mathbf{0 . 0 0 1}$ )

\begin{tabular}{lc}
\hline & SC \\
\hline CR & 0.944 \\
\hline AVE & 0.500 \\
\hline MKR & 0.891 \\
\hline IIT & 0.961 \\
\hline
\end{tabular}

"CR= Composite Reliability, AVE= Average Variance Extracted"

At the second step, the structure (inner) model quality was assessed to check the hypothesized relationships among the constructs. The structural model's predictive performance 
was assessed through PLS algorithm. Gotz et al. (2010) suggested using endogenous variables' determination coefficient $\left(\mathrm{R}^{2}\right)$ for assessing the structural model. The $\left(\mathrm{R}^{2}\right)$ “.... measures the regression function's goodness of fit against the empirically obtained manifest items" (Backhaus et al., 2003). Also, Chin (1998b) suggested using the direction of path coefficients $(\beta)$ and the significance level for evaluating model quality. Table 2 and Figure 2 show the $(\beta)$ and $\mathrm{R}^{2}$ values for the dependent variables. T-statistic as well as path significance level for each of the proposed relationships in the model was obtained through PLS bootstrap method (with 200 resample) employing a one-tailed test as according to Ringle et al. (2005) guidelines. (Figures 2 and Figure 3).

The estimation results of the structural model support our conceptual model as evidenced by the $\mathrm{R}^{2}$ values. Organizational learning, dynamic capabilities, and substantive capabilities constructs have $\mathrm{R}^{2}$ values which explain a moderate amount of variance and the constructs of economic performance and non-economic performance have $\mathrm{R}^{2}$ values which explains a significant amount of variance. This fulfils Chin's (1998a) $\mathrm{R}^{2}$ standards and surpasses Falk and Miller's (1992) $\mathrm{R}^{2}$ cut off of 0.10 . Moreover, the standardized path coefficient values for the all the direct paths in the model (Table 4) were strongly supported at acceptable level of significance $(\mathrm{p}<0.001)$ revealing the relative strength and support of our hypothesized direct relationships (H1, H2 and H3) according to Gefen et al. (2000) criteria.

\section{Table 4}

\section{Structural Model Results}

\begin{tabular}{llllll}
\hline & OL & DC & SC & ECO & NECO \\
\hline $\mathbf{R}^{\mathbf{2}}$ & 0 & 0.347 & 0.246 & 0.755 & 0.791 \\
OL & & H1: 0.578*** & & & \\
DC & & & H2: 0.463*** & & \\
SC & & & & H3a: $\mathbf{0 . 7 8 0 * * *}$ & H3b: $\mathbf{0 . 7 5 3 * * * *}$ \\
\hline
\end{tabular}

PLS Bootstrap (n=200) “† $p<0.10 ; * \mathrm{p}<0.05 ; * * \mathrm{p}<0.01 ; * * * \mathrm{p}<0.001$ n.s. = non-significant” 


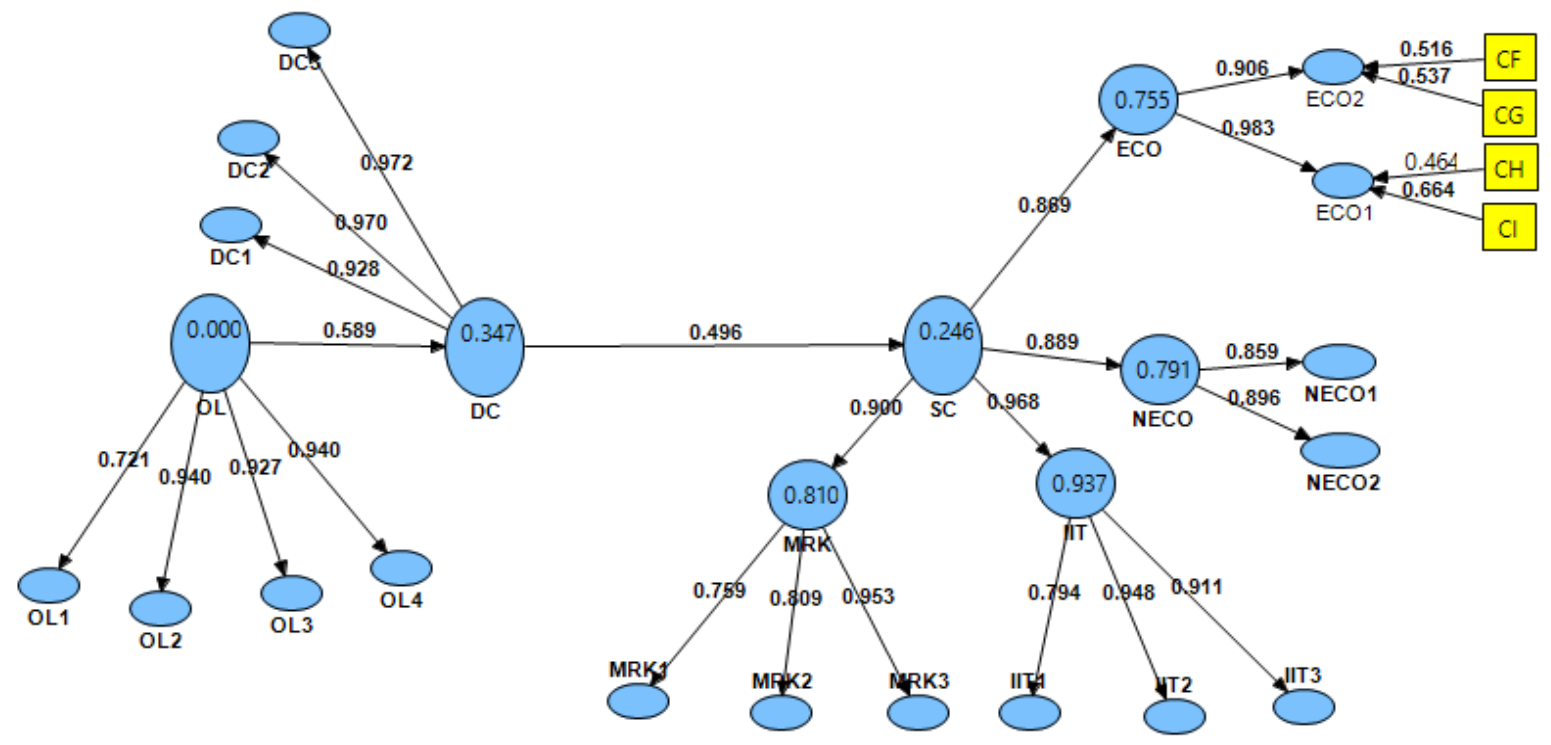

Figure 2: PLS Algorithm Results

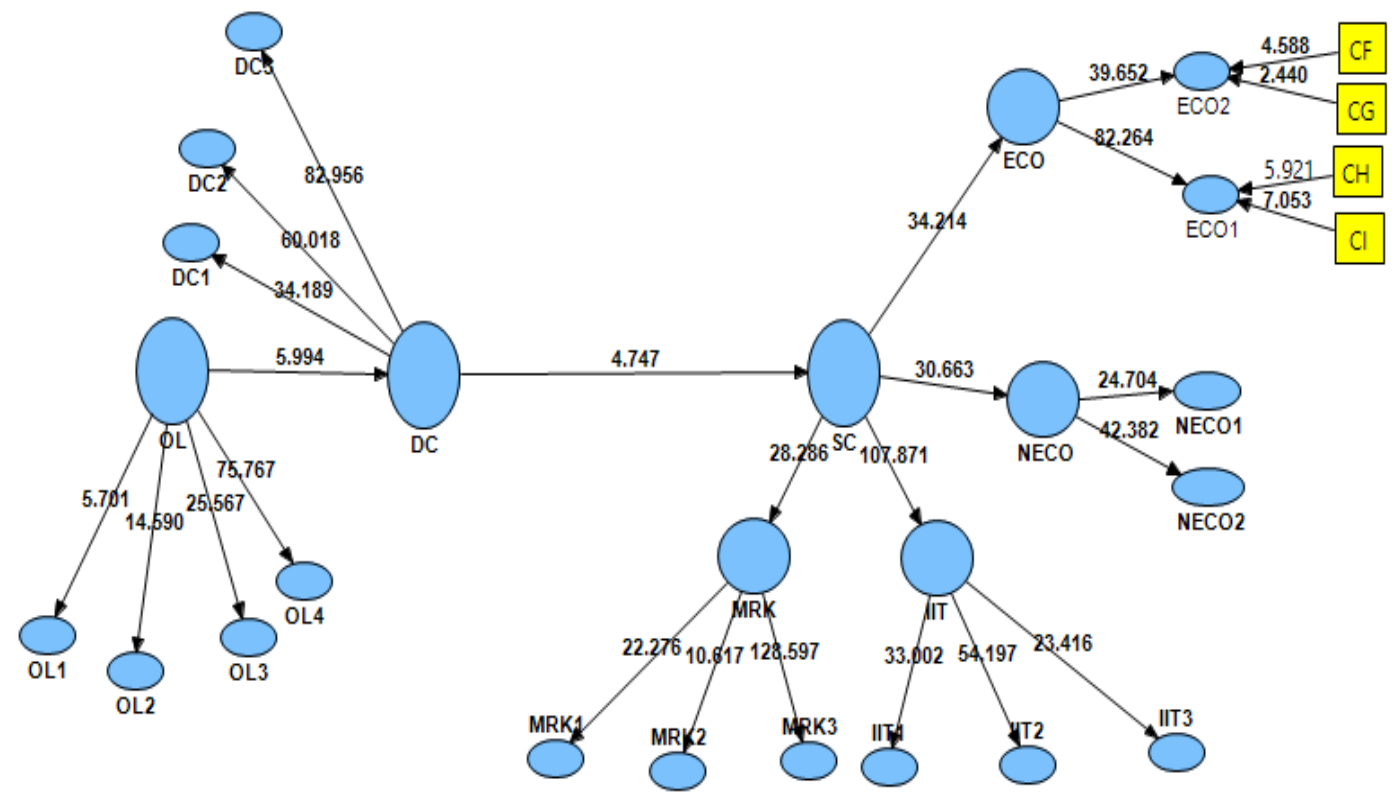

Figure 3: Bootstrap Results 


\subsubsection{Indirect (Mediating) Relationships}

Finally we tested the hypothesized indirect relationships among the constructs in this study using PLS. Table 5 shows the results of our mediation analysis.

\section{Table 5}

\section{Mediating Effects}

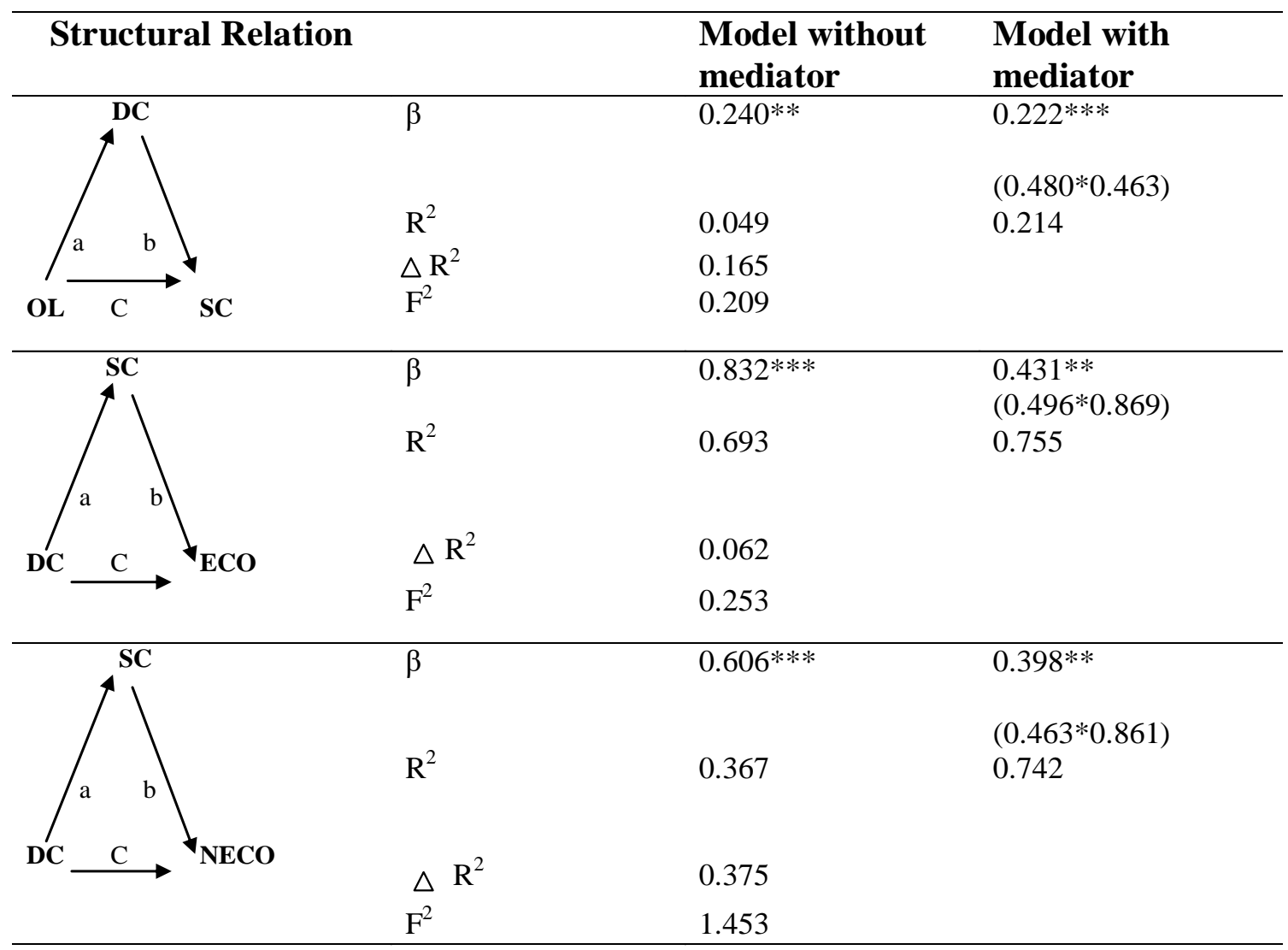

Bootstrap (n=200) “† $\mathrm{p}<0.10 ;{ }^{*} \mathrm{p}<0.05 ; * * \mathrm{p}<0.01 ; * * * \mathrm{p}<0.001, \mathrm{n} . \mathrm{s}=$ non-significant"

PLS has a suitable mediation analysis combined with a causal steps approach based on regression analysis (Gefen et al., 2000 and Welden et al., 2013). Following Holmbeck's (1997) suggestions, we first estimated the model $\left(\beta\right.$ and $\mathrm{R}^{2}$ ) with only the direct effects (path $\mathrm{c}$ in Table 5 ). Then the mediators (Path a, b in Table 5) were added into the model. Both the models were compared then. The results revealed that this addition of the indirect effects decreased the impact of the direct effects in the models. However, the bootstrap significance levels in all cases, although decreased, were still statistically significant, which is an indication that dynamic capabilities partially mediate the effect of the organizational learning construct on substantive capabilities and substantive capabilities construct also partially mediate the effect of dynamic capabilities on both economic and non-economic performance construct according to Chin's (2010: 679) standard. According to Chin (2010) PLS bootstrap is more suitable for assessing the significance of the indirect path for all the relations than Sobel (1982) large sample test. Moreover, the mediating effects were determined by comparing $\mathrm{R}^{2}$ of the models without mediator with the $\mathrm{R}^{2}$ of the models with a 
mediator. Significant impacts of the direct effect on the variance explained in substantive capabilities and economic and non-economic performance constructs were revealed by the results. However, the effect sizes $\left(\Delta \mathrm{R}^{2}\right.$ and $\left.\mathrm{f}^{2}\right)$ were small or moderate only. The direct effect on the variance explained in substantive capabilities was significant. However, the effect size was moderate. While the direct effect on the variance explained for economic and non- economic performance, was significant, with a large effect size.

\subsection{Discussion}

\subsubsection{Direct Relationships}

The findings of our first hypothesis (H1) are consistent with the theoretical arguments of Zollo and Winter (2002), Winter (2003), Crossan and Bedrow (2003), Easterby-Smith and Prieto (2007) among others that learning mechanisms in an organization, specifically knowledge/information acquisition, dissemination, interpretation, and codification shape the development of dynamic capabilities in an organization. That is, the findings identify the factors that help an organization to integrate, reconfigure and renew/ recreate their resources. Pertaining to the hospitality and tourism sector these findings support the work of Nieves and Haller (2014) who assert that in the hotel sector knowledge and familiarity with organizational routines help in integration and coordination by combining the knowledge of employees and coordinating resources. It also supports the work of Liu (2017) who found that the development of the capability of cognitive social capital is enhanced by exploitative learning.

Also, the results for our second hypothesis $(\mathrm{H} 2)$ are in line with the suggestions of Easterby-Smith and Prieto (2007), Danneels (2008), Vargo and Lusch, (2004, 2008), Helfat \& Winter (2011), Leonidou et al. (2015) among others who stated that good operational routines are the results of possessing better dynamic capabilities. It also supports the assertion of Lemmetyinen and Go (2009) that strong partnering abilities and the ability to coordinate cooperation in hospitality business networks are a critical success factor in the future survival of such networks. It is also in line with the findings of Nieves and Haller (2014) in the hotel sector who found that higher levels of human capital (i.e. qualified employees) help develop capabilities to recognize the need for change and alter the resource base accordingly.

Further, the results strongly supported our third hypothesis (H3). These findings reveal and support the ideas of Eisenhardt and Martin (2000), Winter (2003), Zahra et al. (2006) and Helfat and Peteraf (2003), Leonidou, et al. (2015), Wilden and Gudergan (2015) among others who stated dynamic capabilities help improve performance indirectly through the alignments of an organization resources and operational routines. This finding helps clarifies that an organization having good dynamic capabilities will constantly integrate, reconfigure, and renew their substantive or functional capabilities in the form of marketing and technological capabilities in order to achieve good performance. Our results challenge the findings of Leonidou et al. (2015) who found that relationship-building and technology sensing/response were essential for manufacturing firms but not for the hotel industry. 


\subsubsection{Mediating Relationships}

In addition, the results also supported our indirect hypotheses (H4 and H5). The findings for H4 support Collis (1994), Winter, (2003), Capeda and Vera (2005), EasterbySmith and Prieto (2007) capabilities hierarchy concept in management research. Also these findings are in line with the assertions of Nieves and Haller (2014), Fraj et al.'s (2015), Leonidou et al., (2015), Liu (2017) in hospitality and tourism research. These authors were of the view that knowledge based on an organizational learning approach can enhance hotels' capabilities, learning impacts organizational competitiveness indirectly through concrete innovative actions and organizations respond to environmental dynamism through adaptation of their resources which is the result of change processes built on its existing knowledge base.

Also the findings for $\mathrm{H} 5$ confirm the assertions of scholars (e.g., Eisenhardt and Martin, 2000; Winter, 2003; Zahra et al., 2006; Helfat and Peteraf, 2003; Capeda and Vera, 2005; Peteraf et al., 2013; Leonidou et al., 2015) that dynamic capabilities indirectly enhance performance through substantive capabilities. Further, this study investigated the inter-relation between resources and capabilities and hotel performance simultaneously as suggested by Bozic and Cvelbar (2016) and confirmed the prepositions of Liu (2018) that the view of knowledge based on organizational learning approach enhance organization internal capabilities which lead to better performance.

\section{Conclusion and Implications}

\subsection{Theoretical contributions}

The main aim of this study was to examine the way organizational learning effects performance. In order to achieve this aim, this study has made the following academic contributions to both management and hospitality and tourism literature.

First, it provides an integration of co-evolved concepts from the fields of management and hospitality and tourism research. Although it was apparent that both these fields were related and the concepts of organizational learning, capabilities and performance co-evolved in these fields. However, in the past there has been very little attempt to examine the dialogue between these two fields and the researchers mostly used concepts only form their own field. While, this study drew upon the discussions in both these related fields, it extended our understanding by using concepts from both these related fields and proposed and tested an integrative framework which clarified the confusions regarding the organizational learning and performance relationship in both these fields.

Second, it empirically reveals the mediating role of the capabilities' hierarchy in the organizational learning-performance relationship. In this way it clarifies the way organizational learning effects performance, as researchers were divided in their opinion in this regard. It establishes the indirect relationship of organizational learning and performance through capabilities in the hotel industry which has been lacking in research to date (Bozic and Cvelbar. 2016) Also, this study provides a detailed knowledge of how different levels of capabilities are 
interlinked. It provides a unifying framework for zero, first and second order capabilities by clarifying their antecedents and consequences in response to the calls in the management literature (e.g. Prieto et al., 2009; Hung et al., 2010; Chien and Tsai., 2012; Namada, 2017) and to clarify ambiguity in these capabilities and their inter-relationship in the hospitality literature (e.g., Nieves and Haller 2014).

Third, this study used both economic measures and non-economic measures in assessing hotel performance. In this way this study is an attempt to align rigor and relevancy while measuring hotel performance as suggested by Sainaghi et al. (2019). It is also a step towards establishing the manner of measuring hotel performance in relation to organizational learning which has so far not reached a consensus in the literature (Goh et al., 2012).

Finally, the context of this study provides insights into the effect of organizational learning on hotel performance in developed as well as in developing countries hotel context. It confirmed and tested the Ali et al. (2010, 2012) model of market based organizational learning-performance and their measures of hotels' dynamic and substantive capabilities in United Kingdom and Pakistan hotels. The findings reveal the generalizability and applicability of the proposed measures and conceptual framework in both developing and developed countries hotels context. The findings also reveal that hotels which are similar in their nature in relation to ownership and coordination, the impact of technological advancement, customer needs in hotel provision, managerial exposure to different cultures, and connections among the members of the hotel chain have similar effects in terms of the impact of organizational learning on performance - irrespective of their country. These findings are in accordance with Kusluvan and Karamustafa (2001) assertion.

\subsection{Managerial Implications}

Besides theoretical contributions, this study also helps hotel managers understand how hotel capabilities can be developed and the underlying activities and resources that can support their efforts to achieve better performance. Specifically, this study reveals that hotel managers need to be learning oriented, should exploit and explore the internal and external business information and knowledge and convert it into a concrete application (e.g., forming alliances with business partners), conduct market trend analysis, and engage in product and service innovation. Also, in order to expand their products and services and achieve better returns, hotel managers have to find ways to temporarily relinquish their existing capabilities to make way for innovations (e.g., refurbishing existing guest accommodation by adding new facilities, opening mini hotels etc.) in providing services that cater to the customers' needs. Further, they need to coordinate internally as well as externally with their customers, suppliers, competitors, and external stakeholders such as research institutes (i.e. the Institute of Hospitality) to improve the quality of their assortment. In this way, they can help each other by pooling their expertise and developing mutual trust and goals. Moreover, while hotel managers might be tempted to focus on their external operating environment in trying to enhance their organizational performance, it is equally important for them to focus on their internal marketing and technological capabilities development. These capabilities will give them an increased access to their customer and competitor's 
information and timely contact with vendors and suppliers. Most importantly, it will lower their costs of doing business.

\section{Limitations and Future Research Directions}

While considering the contributions of this study, there are of course limitations. First, the service (hotel) sector involves characteristics and challenges that make it unique (Gilbert, 1999). Therefore, the results obtained from hotels having direct contact with customers may not be generalizable to other sectors. Future studies should include manufacturing organizations in order to provide applicability of the conceptual framework in other contexts. Second, future studies might also include hotels (both multinational and national) from other parts of the world, including both developing and developed countries, to further confirm the generalizability and applicability of this framework and the constructs. Third, cross-sectional data were used in this study which provides a view of the current situation only and therefore time-series studies would be used as this may shed further light on the causal nature of the relationships we have examined. Finally, as the link between an organization's environmental conditions and its strategies is an integral part of dynamic capabilities view (Thompson, 1967), future research should also seek to identify any further moderating conditions (e.g., cultural, environmental and economic development factors etc.) that would better inform the dynamic-substantive capabilities relationship.

\section{Acknowledgment}

We thank the "Institute of Hospitality" United Kingdom for their support of the study, and to all the respondents in Pakistan who fill in our survey and provided useful feedback.

\section{Disclosure statement}

There is no potential conflict of interest among the authors. 


\section{References}

Ali, S., Peters, L. D., Lettice, F., 2012. An organizational learning perspective on conceptualizing dynamic and substantive capabilities. Journal of Strategic Marketing. 20(7), 589-607.

Aamna, S. A., Wajiha, K., Madeha, A., Adnan, R., 2010. Determinants of customer satisfaction in hotel industry of Pakistan, European Journal of Scientific Research. 48(1), 97-105.

Ali, S., Peters, L. D., He, H., Lettice, F., 2010. Market based organizational learning, dynamic and substantive capabilities: An integrative framework, Journal of Strategic Marketing, 18 (5), 363377.

Andrews, K. M., Delahaye, B. L., 2000. Influences on knowledge processes in organizational learning: The psychosocial filter. Journal of Management studies. 37(6), 797-810.

Archer, M. S., 1995. Realist social theory: The morphogenetic approach: Cambridge University Press: Cambridge.

Argote, L., Miron-Spektor, E., 2011. Organizational learning: From experience to knowledge. Organization science. 22(5), 1123-1137.

Bartsch, V., Ebers, M., Maurer, I., 2013. Learning in project-based organizations: The role of project teams' social capital for overcoming barriers to learning. International Journal of Project Management. 31(2), 239-251.

Bontis, N., Crossan, M. M., Hulland, J., 2002. Managing an organizational learning system by aligning stocks and flows. Journal of Management studies. 39(4), 437-469.

Božič, V., Knežević Cvelbar, L., 2016. Resources and capabilities driving performance in the hotel industry. Tourism and Hospitality Management. 22(2), 225-246.

Brander Brown, J., McDonnell, B., 1995. The balanced score-card: short-term guest or long-term resident? International Journal of Contemporary Hospitality Management. 7(2/3), 7-11.

Brockman, B. K., Morgan, R. M., 2003. The role of existing knowledge in new product innovativeness and performance. Decision sciences. 34(2), 385-419.

Bustinza, O., Arias-Aranda, D., Gutierrez-Gutierrez, L., 2010. Outsourcing, competitive capabilities and performance: an empirical study in service firms. International Journal of Production Economics. 126(2), 276-288.

Chen, M.-J., Farh, J.-L., MacMillan, I. C., 1993. An exploration of the expertness of outside informants. Academy of Management Journal. 36(6), 1614-1632.

Chien, S.-Y., Tsai, C.-H., 2012. Dynamic capability, knowledge, learning, and firm performance. Journal of Organizational Change Management. 25(3), 434-444.

Chen, X., Zou, H., Wang, D. T., 2009. How do new ventures grow? Firm capabilities, growth strategies and performance. International Journal of Research in Marketing. 26, 294-303.

Chin, W. W., 1998a. Commentary: Issues and opinion on structural equation modelling. MIS Quarterly. 22, 7-16.

Chin, W. W., 1998b. The partial least squares approach to structural equation modeling. Modern Methods for Business Research. 295(2), 295-336.

Chin, W. W., 2010. How to write up and report PLS analyses: in Handbook of Partial Least Square: Concepts, Methods and Applications, Springer, Heidelberg, Dordrecht, London, New York. 655690.

Collis, D. J., 1994. Research note: how valuable are organizational capabilities? Strategic Management Journal. 15(1), 143-152.

Crossan, M. M., Berdrow, I., 2003. Organizational learning and strategic renewal. Strategic Management Journal. 24(11), 1087-1105. 
Danneels, E., 2002. The dynamics of product innovation and firm competences. Strategic Management Journal. 23(12), 1095-1121.

Danneels, E., 2008. Organizational antecedents of second-order competences. Strategic Management Journal. 29, 519-543.

Day, G. S., 1994. Continuous learning about markets. California Management Review. 36(4), 9-31.

Dale, L. G., William, L., Ron, T., 2012. Does RLS Have Advantages for Small Sample Size or Non-Normal Data? MIS Quarterly, 36, 981-1001.

Deeds, D. L., DeCarolis, D., Coombs, J., 2000. Dynamic capabilities and new product development in high technology ventures: An empirical analysis of new biotechnology firms. Journal of Business Venturing. 15(3), 211-229.

Di Stefano, G., Peteraf, M., Verona, G., 2014. The organizational drivetrain: A road to integration of dynamic capabilities research. Academy of Management Perspectives. 28(4), 307-327.

Easterby-Smith, M., Prieto, I. M., 2007. Dynamic capabilities and knowledge management: an integrative role for learning? British Journal of Management 19(3), 235-249.

Eisenhardt, K. M., Martin, J. A., 2000). Dynamic capabilities: what are they? Strategic Management Journal. 21(10-11), 1105-1121.

Falk, R. F., Miller, N. B., 1992. A primer for soft modeling: University of Akron Press.

Faul, F., Erdfelder, E., Lang, A.-G., Buchner, A., 2007. G* Power 3: A flexible statistical power analysis program for the social, behavioural, and biomedical sciences. Behaviour Research Methods. 39(2), 175-191.

Fowler, S. W., King, A. W., Marsh, S. J., Victor, B., 2000. Beyond products: new strategic imperatives for developing competencies in dynamic environments. Journal of Engineering and Technology Management. 17(3-4), 357-377.

Fraj, E., Matute, J., Melero, I., 2015. Environmental strategies and organizational competitiveness in the hotel industry: The role of learning and innovation as determinants of environmental success. Tourism Management. 46, 30-42.

Fujimoto, T., Clark, K. B., 1991). Product development performance: Strategy, organization, and management in the world auto industry. Harvard Business School Press, Boston, MA.

García-Villaverde, P., Elche, M., Martínez-Pérez, D., Ruiz-Ortega, A., 2017. Determinants of radical innovation in clustered firms of the hospitality and tourism industry. International Journal of Hospitality Management. 61, 45-58.

Gefen, D., Straub, D. W., 2000. The relative importance of perceived ease of use in IS adoption: A study of e-commerce adoption. Journal of the Association for Information Systems. 1(1), 8.

Gilbert, N., 2001. Researching Social Life 2nd Edition Sage: London.

Goh, S.C., Elliott, C., Quon, T., 2012. The relationship between learning capability and organizational Performance: Meta-analytic examination. The Learning Organization. 19(2), 92-108.

Gotz, O., Liehr-Gobbers, K., Krafft, M., 2010. Evaluation of structural equation models using the partial least squares (PLS) approach Handbook of Partial Least Squares: Springer: Heidelberg. 691-711

Geller, A.N., 1985. Tracking the critical success factors for hotel companies. The Cornell HRA Quarterly. 76-81.

Helfat, C. E., Finkelstein, S., Mitchell, W., Peteraf, M., Singh, H., Teece, D., Winter, S. G., 2009. Dynamic capabilities: Understanding strategic change in organizations. John Wiley and Sons, New York.

Helfat, C. E., Peteraf, M. A., 2003. The dynamic resource-based view: Capability lifecycles. Strategic Management Journal. 24(10), 997-1010.

Helfat, C. E., Winter, S. G., 2011. Untangling dynamic and operational capabilities: Strategy for the [n] ever-changing world. Strategic Management Journal. 32, 1243-1250. 
Henderson, R., Cockburn, I., 1994. Measuring competence? Exploring firm effects in pharmaceutical research. Strategic Management Journal. 15(1), 63-84.

Hooley, G. J., Greenley, G. E., Cadogan, J. W., Fahy, J., 2005. The performance impact of marketing resources. Journal of Business Research. 58, 18-27.

Holmbeck, G. N., 1997. Toward terminological, conceptual, and statistical clarity in the study of mediators and moderators: Examples from the child-clinical and paediatric psychology literatures. Journal of Consulting and Clinical Psychology. 65(4), 599.

Huber, G. P., 199). Organizational learning: The contributing processes and the literatures. Organization Science. 2(1), 88-115.

Hung, R. Y. Y., Yang, B., Lien, B. Y.-H., McLean, G. N., Kuo, Y.-M., 2010. Dynamic capability: Impact of process alignment and organizational learning culture on performance. Journal of World Business. 45(3), 285-294.

Kaplan, R., Norton, D., 1992. BSC: measures that drives performance. Harvard business review .70 (1), 71-79.

Kusluvan, S., Karamustafa, K., 2001. Multinational hotel development in developing countries: an exploratory analysis of critical policy issues. International Journal of Tourism Research. 3(3), 179197.

Lemmetyinen, A., Go, F. M., 2009. The key capabilities required for managing tourism business networks. Tourism Management. 30(1), 31-40.

Leonard-Barton, D., 1995. Wellsprings of knowledge: Building and sustaining the sources of innovation. Boston. Harvard Business School Press.

Leonidou, L. C., Leonidou, C. N., Fotiadis, T. A., Aykol, B., 2015. Dynamic capabilities driving an eco-based advantage and performance in global hotel chains: The moderating effect of international strategy. Tourism Management. 50, 268-280.

Liu C., 2017. Creating competitive advantage: Linking perspectives of organizational learning, innovation behavior and intellectual capital, International Journal of Hospitality Management. 66, 13-23.

Liu, C.-H. S., 2018. Examining social capital, organizational learning, and knowledge transfer in cultural and creative industries of practice. Tourism Management. 64, 258-270.

Lord, M. D., Ranft, A. L., 2000. Organizational learning about new international markets: Exploring the internal transfer of local market knowledge. Journal of International Business Studies. 31(4), 573-589.

Miller, D., 1987. The structural and environmental correlates of business strategy. Strategic Management Journal. 8(1), 55-76.

Morgan, N. A., 2012. Marketing and business performance. Journal of the Academy of Marketing Science. 40, 102-119.

$\mathrm{Mu}$, J., 2017. Dynamic capability and firm performance: the role of marketing capability and operations capability. IEEE Transactions on Engineering Management . 64 (4), 554-564.

Namada, J. M., 2017. Organizational Learning and Firm Performance: An Empirical investigation in an Emerging Economy Context. International Journal of Business Social Sciences Studies and Research. 1(1), 10-18.

Nieves, J., Haller, S., 2014. Building dynamic capabilities through knowledge resources. Tourism Management. 40, 224-232.

Nonaka, I., Takeuchi, H., 1995. The knowledge-creating company: How Japanese companies create the dynamics of innovation: Oxford university press. New York.

Oh, S. Y., 2019) Effects of organizational learning on performance: the moderating roles of trust in leaders and organizational justice, Journal of Knowledge Management. 23( 2), 313-331. 
Pavlou, P. A., El Sawy, O. A., 2004. From IT competence to competitive advantage in turbulent environments: A dynamic capabilities model. Information Systems Research. 7(3), 198-227.

Prieto, I.M., Revilla, E., 2006. Assessing the impact of learning capability on business performance: empirical evidence from Spain, Management Learning. 37(4), 499-522.

Peteraf, M., Di Stefano, G., Verona, G., 2013. The elephant in the room of dynamic capabilities: Bringing two diverging conversations together. Strategic Management Journal. 34(12), 1389-1410.

Pisano, G. P., 1994. Knowledge, integration, and the locus of learning: An empirical analysis of process development. Strategic Management Journal. 15(1), 85-100.

Prieto, I. M., Revilla, E., Rodríguez-Prado, B., 2009. Building dynamic capabilities in product development: How do contextual antecedents matter? Scandinavian Journal of Management. 25(3), 313-326.

Protogerou, A., Caloghirou, Y., Lioukas, S., 2005. Inside the 'black box' of dynamic capabilities: defining and analyzing their linkages to functional competences and firm performance, Paper presented at the DRUID 10th Anniversary Summer Conference, Copenhagen.

Protogerou, A., Caloghirou, Y., Lioukas, S., 2011. Dynamic capabilities and their indirect impact on firm performance. Industrial and Corporate Change. 21(3), 615-647.

Ramaswami, S., Srivastava, R., Bhargava, M., 2009. Market-based capabilities and financial performance of firms: insights into marketing's contribution to firm value. Journal of the Academy of Marketing Science. 37, 97-116.

Ringle, C. M., Wende, S., Will, A., 2005. SmartPLS 2.0 (beta): Hamburg. Available in http://www. smartpls. de. Accessed on October 05, 2017.

Ringov, D., 2017. Dynamic capabilities and firm performance. Long Range Planning. 50(5), 653-664.

Sainaghi, R., Phillips, P., Baggio, R., Mauria, A., 2019. Hotel performance: Rigor and relevant research topics, International Journal of Hospitality Management. 78, 13-26.

Santos-Vijande, M. L., López-Sánchez, J. Á., Trespalacios, J. A., 2012. How organizational learning affects a firm's flexibility, competitive strategy, and performance. Journal of Business Research. 65(8), 1079-1089.

Shamim, S., Cang, S., Yu, H., 2017. Supervisory orientation, employee goal orientation, and knowledge management among front line hotel employees, International Journal of Hospitality Management. 62, 21-32.

Siggelkow, N., Levinthal, D. A., 2005. Escaping real (non-benign) competency traps: Linking the dynamics of organizational structure to the dynamics of search. Strategic Organization. 3(1), 85-115.

Sin, L. Y., Alan, C., Heung, V. C., Yim, F. H., 2005. An analysis of the relationship between market orientation and business performance in the hotel industry. International Journal of Hospitality Management. 24(4), 555-577.

Sinkula, J. M., 1994. Market information processing and organizational learning. Journal of Marketing. 35-45.

Sirmon, D. G., Hitt, M. A., Ireland, R. D., 2007. Managing firm resources in dynamic environments to create value: Looking inside the black box. Academy of Management Review. 32(1), 273-292.

Sobel, M. E., 1982. Asymptotic confidence intervals for indirect effects in structural equation models. Sociological Methodology. 13, 290-312.

Song, M., Droge, C., Hanvanich, S., Calantone, R., 2005. Marketing and technology resource complementarity: An analysis of their interaction effect in two environmental contexts. Strategic Management Journal. 26(3), 259-276.

Tajeddini, K., Altinay, L., Ratten, V., 2017. Service Innovativeness and the Structuring of organizations: The moderating roles of learning orientation and inter-functional coordination International Journal of Hospitality Management. 65, 100-114 
Takahashi, A., Bulgacov, S., Semprebon, E., Giacomini, M., 2017. Dynamic capabilities, Marketing Capability and Organizational Performance. Brazilian Business Review. 14(5), 466-478.

Teece, D. J., 2007. Explicating dynamic capabilities: the nature and micro foundations of sustainable enterprise performance. Strategic Management Journal. 28(13), 1319-1350.

Teece, D. J., Pisano, G., Shuen, A., 1997. Dynamic capabilities and strategic management. Strategic Management Journal. 509-533.

Tenenhaus, M., Vinzi, V. E., Chatelin, Y.-M., Lauro, C., 2005. PLS path modeling. Computational Statistics and Data Analysis. 48(1), 159-205.

Thomas, R., Wood, E., 2015. The absorptive capacity of tourism organisations. Annals of Tourism Research. 54, 84-99.

Thompson, J. D., 1967. Organizations in action: Social science bases of administration: New York. McGraw-Hill.

Vargo, S. L., Lusch, R. F., 2004. Evolving to a new dominant logic for marketing. Journal of Marketing. 68(1), 1-17.

Vargo, S. L., Lusch, R. F., 2008. Service-dominant logic: continuing the evolution. Journal of the Academy of Marketing Science. 36(1), 1-10.

Vivas López, S., 2005. Competitive advantage and strategy formulation: The key role of dynamic capabilities. Management Decision. 43(5), 661-669.

Vorhies, D. W., Harker, M., Rao, C., 1999. The capabilities and performance advantages of market-driven firms. European Journal of Marketing. 33(11/12), 1171-1202.

Wang, C. L., Ahmed, P. K., 2007. Dynamic capabilities: A review and research agenda. International Journal of Management Reviews. 9(1), 31-51.

Wilden, R., Gudergan, S. P., 2015. The impact of dynamic capabilities on operational marketing and technological capabilities: investigating the role of environmental turbulence. Journal of the Academy of Marketing Science. 43(2), 181-199.

Wilden, R., Gudergan, S. P., Nielsen, B. B., Lings, I., 2013. Dynamic capabilities and performance: strategy, structure, and environment. Long Range Planning. 46(1-2), 72-96.

Winter, S. G., 2003. Understanding dynamic capabilities. Strategic Management Journal. 24(10), 991995.

Zahra, S. A., George, G., 2002. Absorptive capacity: A review, reconceptualization, and extension. Academy of Management Review. 27(2), 185-203.

Zahra, S. A., Sapienza, H. J., Davidsson, P., 2006. Entrepreneurship and dynamic capabilities: A review, model, and research agenda. Journal of Management studies. 43(4), 917-955.

Zgrzywa Ziemak, A., 2015. The impact of organisational learning on organisational performance, Management and Business Administration, Central Europe. 23(4), 98-112.

Zollo, M., Winter, S. G., 2002. Deliberate learning and the evolution of dynamic capabilities. Organization Science. 13(3), 339-351.

Zott, C., 2003. Dynamic capabilities and the emergence of intra-industry differential firm performance: insights from a simulation study. Strategic Management Journal. 24(2), 97-125. 


\section{Appendix A}

\section{List of abbreviations}

Dc= Dynamic Capabilities, IIT= information Technology Related Capabilities, SC= Substantive capabilities, OL= Organizational Learning process, $\mathrm{MKR}=$ Marketing Capabilities, $\mathrm{PERF}=$ Performance, $\mathrm{ECO}=$ Economic Performance, $\mathrm{NECO}=$ Non-Economic Performance

$\mathrm{CR}=$ Composite Reliability, AVE= Average Variance Extracted

\section{Table A.1}

Item measures and descriptive statistics

\begin{tabular}{|c|c|c|c|c|c|}
\hline & $\mathbf{N}$ & Mean & $\begin{array}{l}\text { Skew- } \\
\text { ness }\end{array}$ & Kurtosis & $\begin{array}{l}\text { Std. } \\
\text { Deviation }\end{array}$ \\
\hline \multicolumn{6}{|c|}{ Dynamic Capabilities (Cronbach's Alpha .758) } \\
\hline \multicolumn{6}{|c|}{ Integration DC1 (Cronbach's Alpha .858) } \\
\hline & 240 & 2.03 & 0.379 & -0.248 & 0.777 \\
\hline \multicolumn{6}{|l|}{ DC 1.1} \\
\hline & 240 & 1.72 & 1.042 & 2.489 & 0.712 \\
\hline \multicolumn{6}{|l|}{ DC 1.2} \\
\hline & 240 & 1.95 & 0.216 & -0.517 & 0.708 \\
\hline \multicolumn{6}{|l|}{ DC 1.3} \\
\hline & 240 & 1.8 & 1.139 & 2.257 & 0.774 \\
\hline \multicolumn{6}{|l|}{ DC 1.4} \\
\hline \multicolumn{6}{|c|}{ Reconfiguration DC2 (Cronbach's Alpha .692) } \\
\hline & 240 & 2.22 & 0.149 & -0.919 & 0.918 \\
\hline \multicolumn{6}{|l|}{ DC 2.1} \\
\hline & 240 & 2.09 & 1.008 & 1.140 & 0.935 \\
\hline \multicolumn{6}{|l|}{ DC 2.2} \\
\hline & 240 & 1.89 & 0.858 & 0.025 & 0.96 \\
\hline \multicolumn{6}{|l|}{ DC 2.3} \\
\hline & 240 & 1.93 & 0.513 & -0.317 & 0.807 \\
\hline \multirow{2}{*}{\multicolumn{6}{|c|}{$\begin{array}{c}\text { DC } 2.4 \\
\text { Renewal/re-creation DC3 (Cronbach's Alpha .618) }\end{array}$}} \\
\hline & & & & & \\
\hline DC 3.1 & 240 & 1.5 & 0.734 & -0.417 & 0.594 \\
\hline DC 3.2 & 240 & 1.83 & 1.351 & 2.668 & 0.843 \\
\hline DC 3.3 & 240 & 2.03 & 0.482 & -0.094 & 0.869 \\
\hline DC 3.4 & 240 & 1.74 & 0.522 & 0.042 & 0.667 \\
\hline \multicolumn{6}{|c|}{ Marketing capabilities MKR (Cronbach's Alpha .862) } \\
\hline \multicolumn{6}{|c|}{ Market segmentation and targeting capabilities MKR1 (Cronbach's Alpha .963) } \\
\hline MKR1.1 & 240 & 1.9 & 0.662 & 0.469 & 0.814 \\
\hline MKR1.2 & 240 & 2.28 & 0.740 & 0.936 & 0.84 \\
\hline MKR1.3 & 240 & 2.02 & 1.003 & 1.251 & 0.957 \\
\hline
\end{tabular}


Marketing mix capabilities MKR2 (Cronbach's Alpha .842)

$\begin{array}{lccccc}\text { MKR2.1 } & 240 & 1.88 & 0.132 & -0.713 & 0.663 \\ \text { MKR2.2 } & 240 & 2.18 & 0.765 & 0.460 & 0.996 \\ \text { MKR2.3 } & 240 & 1.83 & 0.984 & 1.333 & 0.813 \\ \text { MKR2.4 } & 240 & 2.03 & 0.750 & 0.377 & 0.934 \\ & & & & \\ \text { MKR3.1 } & 240 & 2.18 & 0.884 & 1.342 & 0.837 \\ \text { MKR3.2 } & 240 & 1.77 & 0.908 & 0.974 & 0.742 \\ \text { MKR3.3 } & 240 & 1.97 & 1.136 & 1.769 & 0.934\end{array}$

Technological-related capabilities IIT (Cronbach's Alpha .813)

Technical proficiency IIT1 (Cronbach's Alpha .988)

IIT 1.1

$\begin{array}{lllll}240 & 2.34 & 0.634 & -0.036 & 0.992\end{array}$

IIT 1.2

$\begin{array}{lllll}240 & 2.28 & 0.456 & -0.093 & 0.777\end{array}$

IIT 1.3

$$
\begin{array}{lllll}
240 & 2.51 & 0.349 & -0.111 & 1.029
\end{array}
$$

Quality Control /regulatory Capabilities IIT2 (Cronbach's Alpha .921)

IIT 2.1

IIT 2.2

IIT 2.3
$240 \quad 3.66$

1.78

$240 \quad 1.78$

$240 \quad 1.86$

$\begin{array}{lll}-0.346 & -1.292 & 1.287\end{array}$

$0.152 \quad-0.486 \quad 0.611$

$0.309 \quad 0.591 \quad 0.612$

IT Infrastructure capabilities IIT3 (Cronbach's Alpha .882)

$\begin{array}{llllll}\text { IIT } 3.1 & 240 & 3.24 & -0.050 & -1.013 & 1.25 \\ \text { IIT } 3.2 & 240 & 2.51 & 0.542 & -0.198 & 1.029 \\ \text { IIT 3.3 } & 240 & 1.82 & 0.032 & -0.230 & 0.58\end{array}$

Organizational Learning OL (Cronbach's Alpha .853)

Knowledge Acquisition OL1 (Cronbach's Alpha .985)

OL 1.1

OL 1.2

OL 1.3

$\begin{array}{lllll}240 & 1.94 & 0.967 & 1.594 & 0.843 \\ 240 & 1.94 & 1.000 & 2.161 & 0.802 \\ 240 & 1.87 & 1.021 & 1.303 & 0.879\end{array}$

Knowledge Dissemination OL2(Cronbach's Alpha .775)

OL 2.1

$\begin{array}{llll}240 & 2.28 & 0.903 & 0.184\end{array}$

1.137 

OL 2.2
240
OL 2.3
$240 \quad 2.28$
0.208
$-0.442$
0.792

Knowledge interpretation OL3(Cronbach's Alpha .820)

OL 3.1

$\begin{array}{lllll}240 & 2.57 & 0.581 & 0.010 & 0.976\end{array}$

OL 3.2

$\begin{array}{lllll}240 & 2.52 & 0.575 & 0.084 & 0.953\end{array}$

OL 3.3

$\begin{array}{lllll}240 & 2.14 & 0.937 & 0.195 & 1.079\end{array}$

Organisational Memory OL4 (Cronbach's Alpha .746)

OL 4.1

$\begin{array}{lllll}240 & 1.55 & 0.792 & 1.027 & 0.592\end{array}$

OL 4.2

$\begin{array}{lllll}240 & 1.82 & 1.021 & 2.136 & 0.698\end{array}$

OL 4.3

$\begin{array}{lllll}240 & 1.68 & 1.087 & 1.282 & 0.745\end{array}$

Organizational Performance OP (Cronbach's Alpha .714)

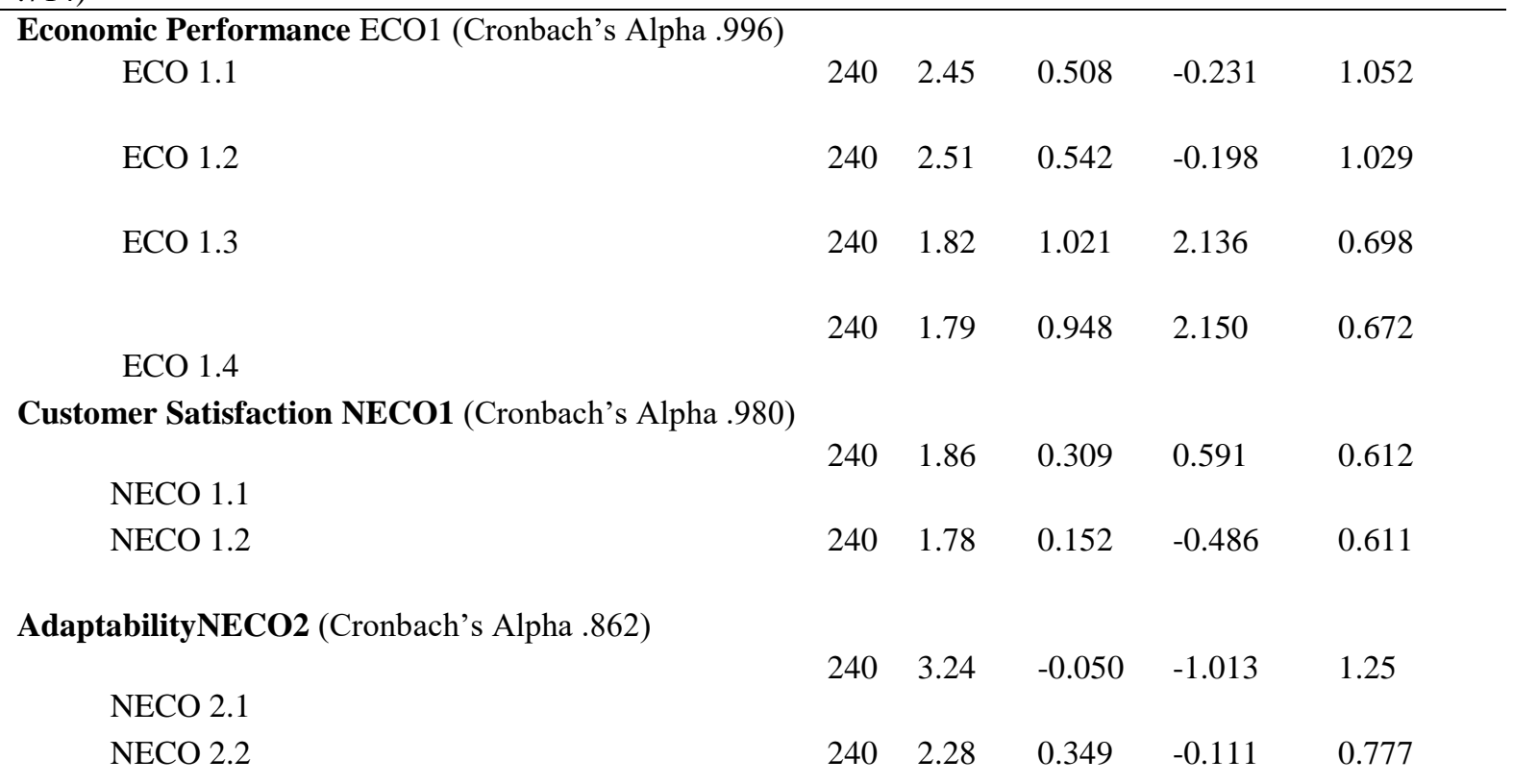


Table B.1

\section{Appendix B}

Item/Indicator loadings and $\mathrm{T}$ value $($ Sig at $\mathbf{P}<\mathbf{0 . 0 0 1})$

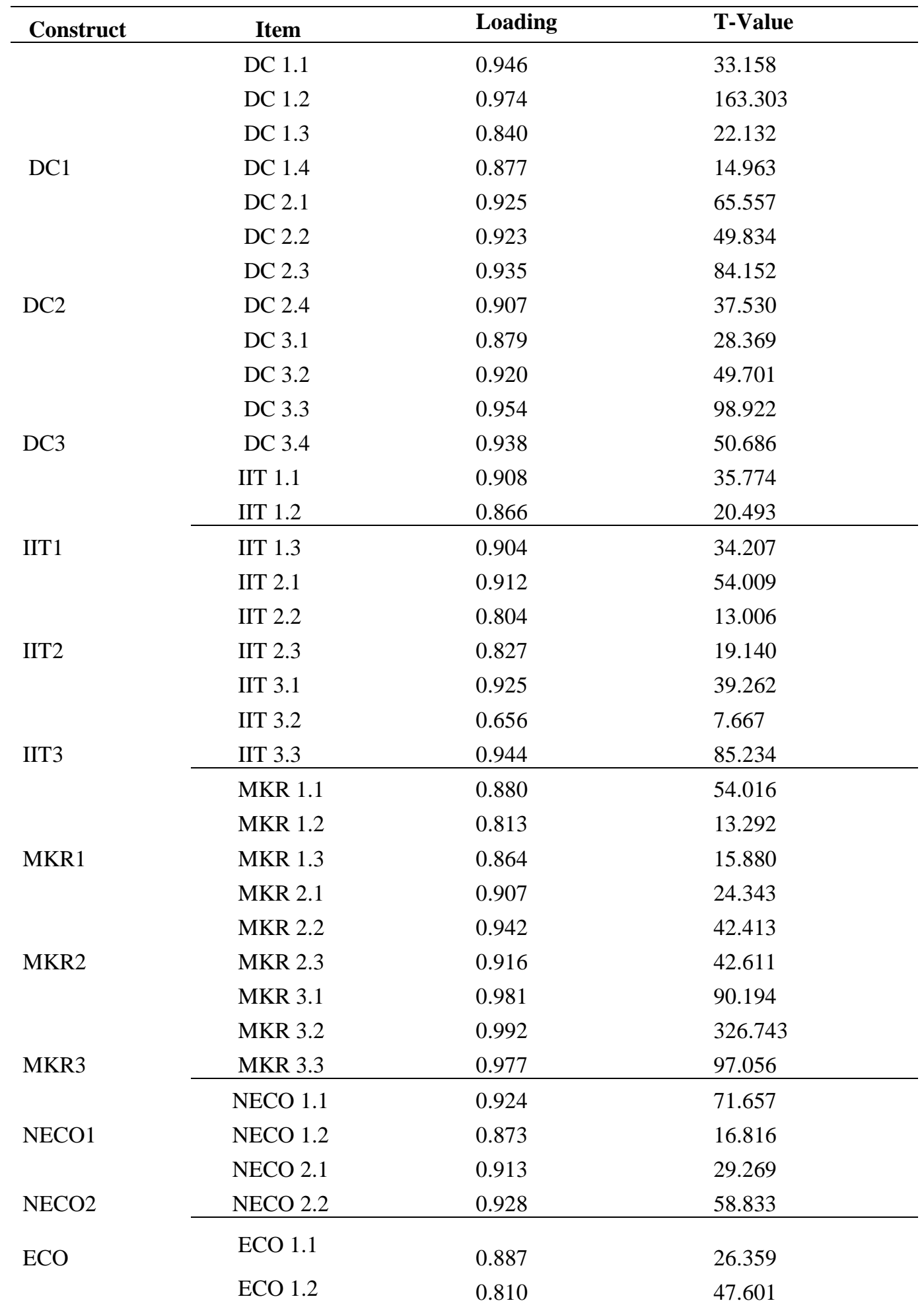




\begin{tabular}{llll} 
& ECO 1.3 & 0.854 & 88.812 \\
& ECO 1.4 & 0.838 & 49.586 \\
\cline { 2 - 3 } OL1 & OL 1.1 & 0.964 & 115.810 \\
& OL 1.2 & 0.934 & 46.423 \\
& OL 1.3 & 0.865 & 18.567 \\
OL2 & OL 2.1 & 0.937 & 54.715 \\
& OL 2.2 & 0.962 & 54.300 \\
OL3 & OL 2.3 & 0.876 & 21.835 \\
& OL 3.1 & 0.893 & 31.037 \\
& OL 3.2 & 0.930 & 46.226 \\
OL4 & OL 3.3 & 0.914 & 33.506 \\
\hline
\end{tabular}

